\title{
Paradigma Pendekatan Spiritual dalam Layanan Bimbingan dan Konseling di Lembaga Pendidikan Islam
}

\author{
Puspo Nugroho \\ STAIN Kudus, Jawa Tengah, Indonesia \\ pusponugroho@stainkudus.ac.id
}

\begin{abstract}
Abstrak
Peserta didik sebagai manusia yang sedang berproses tentu tidak bisa terlepas dari yang namanya problem. Berbagai konflik internal yang muncul dari dalam pribadi yang berujung pada munculnya kenakalan remaja atau dalam istilah lain disebut juvenile delinquency tidak bisa terelakkan. Munculnya perbuatan yang melanggar norma, aturan atau hukum dalam masyarakat yang dilakukan pada usia remaja atau transisi masa anak-anak dan dewasa pada jenjang sekolah banyak kita temukan. Guru sebagai orang tua kedua turut andil dan bertanggung jawab terhadap pemecahan problem tersebut. Dari sinilah guru sebagai bagian dari lembaga pendidikan harus ikut andil menyelesaikan persoalan tersebut. Berbagai lembaga khususnya yang berlatar belakang Islam mulai mencoba menerapkan pendekatan-pendekatan berbasis Islam/pendekatan illahiyah sebagai bagian dari proses konseling peserta didik. Amalan-amalan, wirid, kajian rutin keislaman serta berbagai pendekatan Islam terapan menjadi langkah utama bagaimana lembaga pendidikan membangun lingkungan dengan nilai nilai Islami yang mampu memberikan pengaruh terhadap psikis peserta didik. Dengan demikian Kenakalan remaja atau juvenile delinquency mampu diminimalisir bahkan dihilangkan.
\end{abstract}

Kata Kunci: Bimbingan dan Konseling; Pendekatan Spiritual; Kenakalan Siswa; Lembaga Pendidikan.

\section{Abstract}

Students as human beings who are in the process certainly cannot escape the problem. Various internal conflicts that arise from within the person that lead to the emergence of 


\section{Paradigma Pendekatan Spiritual dalam Layanan Bimbingan ...}

juvenile delinquency or in other terms called juvenile delinquency can not be avoided. We find many actions that violate the norms, rules or laws in society that are carried out in adolescence or the transition of childhood and adulthood at the school level. The teacher as the second parent contributes and is responsible for solving the problem. This is where the teacher as part of the educational institution must contribute to solve the problem. Various institutions, especially those with an Islamic background, began to try to apply the Islamicbased approaches/illahiyah approaches as part of the counseling process of students. Practices, wirid, routine Islamic studies and various applied Islamic approaches are the main steps in how educational institutions build environments with Islamic values that can influence students psychologically. Thus juvenile delinquency can be minimized and even eliminated.

Keywords: Guidance and Counselling; Spiritual Approach; Student Delinquency; Educational Institutions.

\section{A. Pendahuluan}

Dalam proses kehidupan saat ini, Khususnya masa remaja adalah masa yang penuh dengan gejolak jiwa, masa dimana seorang remaja belajar menemukan jati diri melalui berbagai aktifitasnya. Tidak jarang seorang remaja juga mengalami sebuah masa dimana diri dan jiwanya terombang ambing. Dalam posisi ini orang terdekat sangat berperan penting dalam proses dimana seorang individu mengenal dan mengembangkan dirinya. Masa usia sekolah adalah masa dimana anak memiliki kecenderungan bersosialisasi secara kelompok.

Pada saat ini tidak jarang kita temui baik pada surat kabar, media cetak dan media sosial fenomena kenakalan remaja, seperti siswa yang melakukan minum-minuman keras, tawuran antar pelajar, kasus bullying, karakter siswa yang keras baik terhadap teman maupun gurunya dan masih banyak kasus lainya menjadi dilema dan tentunya baik orang tua, pengelola lembaga pendidikan serta Guru harus turut andil bersama-sama menyelesaikan permasalahan-permasalahan tersebut. 
Seting kehidupan seorang anak baik di lingkungan pendidikan maupun di lingkungan masyarakat tentunya syarat akan perbedaan, terlebih di Indonesia yang notabennya sangat multikultural. Keberagaman budaya dan agama yang terdapat didalam kehidupan masyarakat, tentu berimbas pada pola kehidupan masyarakat yang memberikan perbedaan terhadap keyakinan nilai, cara pandang, sampai kepada pemahaman terhadap aspek-aspek diri yang berpengaruh terhadap tingkah laku (Syafri and Rifa 2017). Anak sebagai manusia memiliki sifat-sifat yang selalu berubah. Keberadaannya tidaklah terbatas ataupun statis, manusia dapat berubah ketika situasi maupun keberadaannya berubah karena manusia dapat membangun sebuah mekanisme adaptasi dalam perubahan (Nugroho 2017). Hal ini menjadi tantangan tersendiri seorang guru dalam proses pengembangan potensi peserta didik.

Anak anak ibarat sebuah biji buah yang pada saatnya biji tersebut akan tumbuh dan berkembang. Dalam proses pertumbuhan dan perkembanganya tentunya harus dipersiapkan, dirancang dengan baik dan matang sehingga kelak biji tersebut dapat tumbuh dan berkembang sesuai kodratnya. Tidak sedikit anak tumbuh dan berkembang justru tidak sesuai kodratnya, hal tersebut tentunya sangat dipengaruhi oleh kondisi lingkungan dimana anak tersebut berada. Anak tersebut akan tumbuh dengan baik manakala kondisi lingkungan dimana ia berada juga mendukung, akan tetapi apabila kondisi lingkungan dimana ia berada tidak kondusif tentunya akan berbanding terbalik dan yang jadi seorang anak tersebut tidak akan tumbuh dengan sempurna.

Ibarat contoh biji kacang hijau yang ditanam pada dua bejana, yang satu diletakkan di dalam ruang tertutup dan yang satunya diletakkan berdekatan dengan sinar matahari. Dalam hal ini biji kacang hijau tersebut akan mengalami proses pertumbuhan yang berbeda dari keduanya. Antara yang dekat dengan sinar matahari dengan yang tidak mendapatkan cahaya sinar matahari. Sinar matahari disini diibaratkan sebagai stimulus yang diberikan kepada biji yang ditanam tersebut. Anak yang dididik di lingkungan yang kondusif akan tubuh dan berkembang mengikuti pola dan kondisi dimana lingkungan pendidikan tempat ia berkembang. Peran 


\section{Paradigma Pendekatan Spiritual dalam Layanan Bimbingan ...}

lembaga pendidikan menjadi penting dalam rangka menciptakan suasana dan kondisi lingkungan yang baik.

Proses pendidikan seorang siswa baik dari tingkat dini, dasar, menengah, atas hingga perguruan tinggi tentu tidak akan bisa terlepas dari yang namanya problematika. Allah telah memberikan peringatan kepada setiap manusia bahwa dunia ini adalah sebagai tempat ujian, agar manusia senantiasa tidak hanyut dalam kehidupan dunia yang fana dan menyesatkan. Menyesatkan dalam hal ini adalah karena sejatinya kehidupan didunia ini lebih didominasi oleh sifat yang tidak baik. Semua kesenangan dan kenikmatan yang disuguhkan oleh dunia bisa saja menjadikan manusia terlena dan melupakan Tuhannya. Pada posisi inilah dunia menjadi sebuah ujian.

Memasuki era generasi millenia saat ini, tidak bisa dipungkiri arus globalisasi dan perkembangan teknologi yang semakin cepatnya sangat berpengaruh terhadap perkembangan peserta didik. Arah perkembangan tersebut ada dua hal yaitu positif dan negatif. Bagaimana pribadi-pribadi mampu mengarahkan dirinya atau justru terseret terbawa arus tergantung dari dirinya dan lingkungan dimana ia berada. Apabila tidak dibangun system yang baik bisa jadi akan membawa dirinya ke arah negatif dan tentunya akan merusak pribadi individu tersebut. Sebaliknya apabila pribadi dan system lingkungan mampu mengarahkannya pada hal yang sifatnya positif tentunya akan menjadi pribadi yang berkualitas.

Selain arah perkembangan tersebut, perlu kita cermati bersama bahwa manusia cenderung selalu dihadapkan pada dua kemungkinan, baik atau buruk, kelapangan dan kenikmatan, kesempitan dan musibah. Ujian atau cobaan hidup yang dihadapi setiap individu di dunia selalu muncul dua kemungkinan, bisa berupa kesempitan dan musibah, namun terkadang juga berupa kelapangan dan kenikmatan. Bisa juga berupa kondisi sehat maupuan kondisi sakit, bisa berupa kekayaan maupun kemiskinan. Seorang mukmin akan selalu dihadapkan pada dua kemungkinan yang tentu manusia tidak bisa menghindarinya dan harus menghadapi ujian dalam dua keadaan diatas, kondisi susah dan kondisi senang. Disinilah kemudian dikatakan bahwa dunia adalah tempat dimana manusia diuji, dunia sebagai bentuk ujian. 
Hadirnya proses layanan bimbingan dan konseling dalam lingkungan pendidikan di Indonesia merupakan sebuah bangunan integral yang tak terpisahkan. Kegiatan bimbingan dan konseling tidak bisa dilakukan secara serampangan dan bahkan harus dilaksanakan secara profesional. Para proses pelaksanaanya perlu berangkat dan berpijak dari suatu landasan yang kokoh yang disandarkan dari hasil-hasil pemikiran dan penelitian yang mendalam. Melalui adanya pijakan yang jelas dan kokoh diharapkan dalam proses pengembangan layanan bimbingan dan konseling, baik yang bersifat teoritik maupun praktek mampu tampil menjembatani setiap problematika klien serta mampu memberikan manfaat besar bagi kehidupan, terutama bagi para penerima jasa layanan (klien).

Melihat tujuan diatas serta harapan agar dalam pelaksanaan bimbingan dan konseling tidak terjebak dalam berbagai bentuk penyimpangan yang dapat merugikan klien, maka seorang konselor perlu jeli dan cermat serta memiliki pemahaman dan penguasaan terhadap landasan bimbingan dan konseling.

Munculnya beberapa kasus kesalahkaprahan lebih-lebih kasus malpraktek yang terjadi dalam proses layanan bimbingan dan konseling tidak jauh dari pengaruh kesan yang muncul pada proses layanan bimbingan dan konseling yang cenderung seperti "polisi sekolah", atau persepsi bahwa seorang anak yang salah harus dihakimi, diadili bahkan dihukum melalui proses layanan BK. Dengan kata lain, proses penyelenggaraan bimbingan dan konseling dilakukan secara asal-asalan, tidak dibangun di atas landasan yang seharusnya.

Sebagai mana kita ketahui bahwa bimbingan konseling memiliki beberapa landasan seperti landasan religius, psikologi, budaya, filosofis, pedagogis, historis dan landasan legalistik. Islam sebagai agama yang dibawa oleh Rosulullah Muhammad saw hadir menjadi landasan untuk memberikan solusi dan jawaban terhadap munculnya berbagai problematika yang ada pada setiap masa. Ayat demi ayat turun untuk memberikan jalan keluar dari setiap persoalan. Problematika yang muncul selalu ada solusinya apabila manusia kembali kepada pedomannya, yaitu Al-Qur'anul karim. Maka pada intinya Islam sebagai agama memiliki fungsi yaitu berisi kebaikan dan perbaikan, mencegah dari segala macam bentuk mara 


\section{Paradigma Pendekatan Spiritual dalam Layanan Bimbingan ...}

bahaya dan kerusakan, mengajak kepada kebaikan dan petunjuk serta memberi peringatan supaya menjauhi kejelekan dan segala macam perbuatan nista.

Dalam situasi dunia yang semakin global, ilmu agama dituntut dapat memberikan solusi sekaligus jawaban terhadap berbagai persoalan aktual. Hal ini berkaitan dengan adanya keyakinan bahwa ilmu agama pasti mengandung nilai-nilai universal dan absolute yang mampu memberikan alternative yang tidak ada habisnya (Ibrahim 2014). Disinilah agama hadir sebagai pendekatan dalam proses layanan bimbingan dan konseling bagi individuindividu peserta didik yang sedang mengalami problem. Dengan pendekatan berbasis religius diharapkan individu akan mampu bangkit dari keterpurukan fisik maupun psikis yang menjangkitinya.

Hal ini ditegaskan oleh Jalaludin bahwa dalam diri manusia memiliki bentuk ikatan hidup yang mengandung pengakuan pada suatu sumber yang berada di luar diri manusia yaitu agama, agama sangat mempengaruhi dan bahkan melandasi perbuatan-perbuatan manusia sehingga timbul pengakuan akan adanya kewajibankewajiban yang diyakini dan harus dilaksanakan (Jalaludin 2010).

Islam sebagai salah satu agama yang mayoritas dianut oleh masyarakat Indonesia hadir sebagai solusi setiap permasalahan. Setiap problem yang terjadi pada kehidupan masyarakat, Islam hadir sebagai solusi pemecahanya, memberikan jawaban dan jalan keluar bagi setiap permasalahan. Dalam dunia pendidikan saat ini, Bisa kita simak secara seksama masuknya mata pelajaran Pendidikan Agama Islam tidak lain adalah untuk memberikan sumbangsih melalui hadirnya Islam yang tidak hanya sebagai agama, Islam yang tidak hanya sebagai ilmu pengetahuan tetapi lebih dari itu, bagaimana Islam hadir mengisi kekosongan-kekosongan yang saat ini terjadi. Islam hadir sebagai jalan keluar, solusi berbagai problematika yang dihadapi oleh individu, dalam hal ini peserta didik. Modal spiritual mempunyai fungsi salah satunya adalah menjadi guardian (pelindung) terhadap penyimpangan (Adi 2008:317).

Dalam konteks ini, bisa kita simpulkan bahwa setiap individu tidak terlepas dari yang namanya masalah, begitupula seorang peserta didik. Guru dalam hal ini serorang Konselor pendidikan sebagai orang tua di lingkungan sekolah/madrasah mempunyai andil 
besar dimana kehadiranya tidak hanya sekedar sebagai aktor transfer of knowladge, tetapi bisa masuk pada ruang-ruang khusus yang tidak jarang orang tua kandungnya tidak mampu memasukinya. Pada posisi inilah penulis ingin mengetengahkan sebuah paradigma Islam sebagai Ilmu Terapan yang memiliki peran sebagai pendekatan dalam proses layanan bimbingan dan konseling peserta didik.

Dalam pelaksanaanya, kajian ini lebih bersifat kualitatif dengan pendekatan studi kepustakaan (library research). Menurut Mahmud, Library research ialah serangkaian kegiatan yang berhubungan dengan metode pengumpulan data-data yang sifatnya pustaka (Mahmud 2011). Aspek yang diteliti adalah nilai nilai agama sebagai bagian tak terpisahkan dari praktik konseling pendidikan.

\section{B. Pembahasan}

\section{Konsep Spiritualitas dalam Pelaksanaan Konseling}

Pada persoalan konsep spiritual tidak bisa terlepaskan dari term struktur agama. Apapun agama seseorang dipastikan memiliki tingkat spiritualitas. Akan tetapi spiritualitas bukanlah agama itu sendiri meskipun adanya spiritualitas membutuhkan struktur yaitu agama. Menurut Cashwell \& Young, (2011) Spiritualitas bersifat internal, spontan, universal (Kilmer 2012:3). Spiritualitas merupakan sebuah perasaan yang memiliki kedekatan dan keterhubungan yang lebih kepada yang bersifat suci dan sakral.

Menurut Gerald Corey, EdD Diplomate di Counseling Psychology, ABPP Professor Emeritus of Human Services and Counseling California State University, Fullerton menjelaskan dalam pengantar Integrating Spirituality and Religion Into Counseling a guide to competent practice bahwa nilai-nilai spiritual dan agama dapat memainkan peranan utama dalam kehidupan manusia, nilainilai ini harus dilihat sebagai sumber potensial dalam konseling (Cashwell and Young 2011:viii).

\section{Teknologi Keberagamaan Islam}

Berbicara mengenai teknologi tidak serta merta berkaitan dengan hal hal yang sifatnya modern, kebaruan, alat yang canggih yang berasal dari barat, akan tetapi dalam hal ini lebih bersifat nilai aplikatif dan kebermanfaatan dari suatu objek. Teknologi 


\section{Paradigma Pendekatan Spiritual dalam Layanan Bimbingan ...}

keberagamaan menjadi teramat penting untuk solusi jawaban kebutuhan masyarakat modern saat ini yang perlu kita kembangkan sebagai solusi pemecahan masalah. Menurut Muslim menuturkan sifat masalah yang dihadapi oleh umat Islam Indonesia adalah kenyataan praktis dalam keseharian masyarakat yang tidak seperti yang diharapkan oleh ajaran Islam (Kadir 2003, 241). menurutnya solusi pemecahan masalah yang tepat adalah paradigma terapan.

Perkembangan keilmuan lebih-lebih keilmuan Islam harus didorong dan diarahkan untuk mampu menyelesaikan masalah peserta didik yang bersifat pribadi, keluarga dan masyarakat. Bukan hanya sekedar berfikir bagaimana seharusnya atau bagaimana konsep pemikiranya, akan tetapi harus mampu menjawab sebagai suatu bentuk praktik beginilah seharusnya yang bersifat aplikatif, psikomotorik dan wujud nyata. Bukan hanya sekedar berbicara melainkan harus mampu menunjukkan dalam sebuah aktifitas dan wujud tindakan nyata.

Berbagai bentuk demoralisasi baik dikalangan elit maupun pada tataran bawah, mulai dari korupsi, kolusi, nepotisme, pembunuhan dan kekerasan. Sebagai contoh nyata dalam kurun waktu Januari hingga Maret 2018 setidaknya sebanyak 23 kasus anak mengalami kekerasan. Dari 23 kasus itu, 16 anak di antaranya meninggal di tangan orang tuanya (republika.co.id.). Kasus lainya adalah terungkapnya kematian remaja dan 10 tersangka pesta spirtus di sukabumi jawabarat. Selain itu seorang pelajar Sekolah Menengah Atas (SMA) di Makassar ditangkap polisi, akibat terlibat dalam peredaran narkoba. Pelaku dibekuk dengan barang bukti sabu sebanyak 24 paket (https://news.detik.com) dan sederet kasus penyimpangan remaja lainya menjadi potret suram keadaan pemuda negeri ini. Realita tersebut adalah potret dari sebuah gejolak individu yang berimplikasi pada kerusakan. Khususnya pada posisi seorang anak yang mengalami tekanan entah disebabkan oleh hal apapun, menurut Stanley Hall sebagaimana dikutip Muhtar menyatakan bahwa masa-masa remaja merupakan masa penuh gejolak, emosi yang tidak seimbang yang tercakup dalam "storm" dan "stress"(Muhtar 2014: 251).

Manusia sebagai makhluk ciptaan Tuhan memiliki beberapa unsur yang menyatu dalam diri manusia yaitu fisik atau raga, jiwa 
dan ruh. Dijelaskan oleh Syamsul Bachri Thalib (2010: 125) dalam kajian penelitian Kaplan et al., secara empiris dilaporkan bahwa rendahnya konsep diri berkorelasi positif antara lain terhadap perilaku kekerasan, prasangka, dan gangguan mental. Apabila siswa dibiarkan tanpa konsep diri yang sesuai, maka hal-hal negatif tersebut tidak bisa dipungkiri akan terjadi pada siswa. Kurangnya informasi mengenai bimbingan spiritual pada siswa berakibat pada minimnya pengetahuan remaja akan kebutuhan dan sikap spiritual yang seharusnya dimiliki dan diamalkan.

Bimbingan adalah proses pemberian bantuan yang dilakukan oleh orang yang ahli dalam hal ini seorang konselor kepada seseorang atau beberapa orang individu, baik anak-anak, remaja, maupun dewasa; dalam hal ini seorang konseli/klien agar orang yang dibimbing dapat mengembangkan kemampuan dirinya sendiri dan mandiri; dengan memanfaatkan kekuatan individu dan sarana yang ada dan dapat dikembangkan; berdasarkan norma-norma yang berlaku (Amti 2008). Tugas konselor adalah menawarkan undangan kepada klien untuk mengatasi masalah apa pun yang penting dalam kehidupan mereka, yang dilakukan dengan menyediakan iklim yang tidak menghakimi dan menerima.

Dewasa ini menjadi perlu melakukan pergeseran paradigma dari yang sifatnya normatif filosofi menuju terapan. Pergeseran ini justru semakin mendekatkan pola keberagamaan umat Islam menuju lingkup al-Qur'an dan Sunnah. Perlu kita tengok bersama bahwa perjalanan turunya al-Qur'an dan Sunnah selalu diawali dengan munculnya problematika baru kemudian diikuti oleh sebuah jawaban-jawaban bagi yang sifatnya kalam Allah ataupun Sunnah. Hal ini juga dijelaskan oleh Fazlur Rahman memandang bahwa Islam lahir dari kehidupan praktis dan ditujukan untuk menghadapi dan memecahkan masalah praktis (Rahman 1964). Apabila pergeseran paradigma ini berjalan dan mampu diterapkan oleh masyarakat muslim kedepan akan lahir generasi yang sehat baik jazmani maupun rohani yang ujungnya terciptanya insan khamil.

Mempelajari agama bukan hanya sekedar sebagai sebuah doktrin semata, melainkan bagaimana juga mampu mengerti secara empirik yang sifatnya ilmiah. Ibarat kata berbicara mengenai puasa bahwasanya manusia diwajibkan untuk berpuasa sebagaimana 
ditegaskan dalam Qs. Al baqoroh ayat 183, melainkan juga berfikir hikmah atau rahasia ilmiah apa dibalik manusia diperintahkan untuk berpuasa tersebut. Penggabungan antara konsep doktrin dan scientific menjadi keniscayaan yang harus mulai dikedepankan, dalam hal ini menjadi landasan epistemologi keilmuan. Meminjam istilah A. Mukti Ali metode penggabungan ini disebut sebagai metode Scientific cum-doktriner (A Mukti 1991). Lingkup kajian ini lebih pada bagaimana membangun sebuah paradigma dimensi empiris keberagamaan yang dapat diamati tentunya melalui peran bimbingan dan konseling.

Pada posisi ini al-Qur'an dan Sunnah diposisikan sebagai sumber yang bersifat doktrinal. Sebagai contoh pengertian Iman sebagaimana penjelasan yang dituturan oleh Muhammad Iqbal bahwa Iman bukan hanya sebatas percaya, akan tetapi memiliki unsur mengerti (Iqbal 1940). Maka dari itu seseorang yang beriman memungkinkan memiliki peluang untuk mengerti kandunganya dan implikasi dari firman-firman Allah tersebut baik melalui wahyu dan sunnah ataupun terapanya dalam kehidupan praktis.

\section{Pendekatan Agama Islam berbasis Psikoterapi Religius sebagai solusi Alternatif}

Islam sebagai agama rahmatan lil 'alamin hadir sebagai pembawa rahmat bagi alam semesta. Hal ini selain mengandung makna vertikal juga mengandung makna horisontal. Islam sebagai agama dengan konsep rahmatan lil alamin yang pada hakikatnya ditujukan kepada dan untuk kesejahteraan seluruh alam, maka hakikat agama ini merupakan universalitas kemanusiaan. Maksudnya vertikal adalah bahwa statement diatas merupakan kalam Allah yang terdapat dalam Qs. Al Anbiya' ayat 107. Ini menjadi doktrin sekaligus mampu memberikan sebuah konsep paradigma universalitas kemanusiaan. Akan tetapi disisi lain pada makna yang bersifat horisontal tersebut perlu kita kaji bersama. Dimana Islam hadir sebagai rahmat seluruh alam akan tetapi kita bisa tengok bersama khususnya di negara indonesia yang mayoritas berpenduduk muslim belum menampakkan wujud mensejahterakan manusia (Kadir 2003).

Melihat realita dilapangan, jika kita perhatikan kesejahteraan kehidupan dunia baik individu, berkeluarga maupun bermasyarakat 
yang berkelimpahan harta lahiriah dan kekayaan material tidaklah cukup untuk menghantarkan pada tingkat kehidupan yang tenteram dan bahagia. Bisa kita tengok seksama masyarakat pengidap penyakit jantung dan lain sebagainya justru didominasi dari kalangan menengah keatas. Kecenderungan gaya hidup hedonis, bermewah mewahan atau yang lebih parah lagi bergaya sosialita padahal realita keadaan tidak mendukung untuk bermewah mewahan menjadi budaya akhir-akhir ini. Masyarakat seakan kurang percaya diri jika tampil di publik tidak dengan menggunakan barang yang bermerek, berkelas dan mahal.

Fenomena diatas apabila tidak menjadi perhatian dan dibiarkan bisa berdampak pada ketidaksiapan masyarakat menghadapi situasi yang demikian. Efek parahnya bisa dipastikan individu atau masyarakat tidak siap dengan kondisi demikian maka menurut Alvin Toffler akan terjadi keguncangan jiwa atau dalam istilahnya disebut future shock (Syukur 2003: 3).

Agama menjadi bagian penting dalam kehidupan manusia. Tanpa agama manusia dipastikan akan mengalami kekeringan batin. Pembangunan kemajuan fisik semata tanpa diimbangi dengan pembangunan mental spiritual akan menjadikan seorang individu mengalami kegonjangan batin. Ekspektasi atau harapan yang terlalu tinggi yang tidak diimbangi dengan melihat Realitas kehidupan bisa berakibat pada kekecewaan yang mendalam. Dalam kasus ini sebagaimana terjadi pada Prof. Paul Ehrenfets seorang guru besar fisika berkebangsaan Belanda dengan seorang anak. Ia menginginkan putra satu satunya menjadi anak yang pandai dan cerdas seperti dirinya, akan tetapi harapanya tak kunjung tercapai, justru anaknya memperlihatkan penurunan yang drastis yang pada akhirnya sang profesor justru mengakhiri kehidupan sang anak dan bunuh diri. Sebelumnya ia sempat menuliskan sepucuk surat kepada teman karibnya Prof. Konstamm yang berisi "yang tidak ada pada diri saya adalah kepercayaan kepada tuhan, agama itu perlu. Barang siapa yang tidak mampu memiliki agama, ia akan binasa"(Syukur 2003).

Dari kasus diatas bisa kita ambil kesimpulan bahwa agama memiliki peranan penting dalam kehidupan manusia. Seseorang yang jiwanya kosong dari agama (akidah) akan mengalami kecenderungan ketidaktenangan, resah, gelisah dan sedikitpun tidak ada ketenangan 


\section{Paradigma Pendekatan Spiritual dalam Layanan Bimbingan ...}

batin dan kebahagiaan dalam kehidupannya. Diri manusia tidak bisa terlepaskan dari yang namanya agama. Mengambil istilah Ana-Maria Rizzuto (1979:47) yang dikutip oleh Pargement "[Religion] is an integral part of being human, truly human in our capacity to create nonvisible, but meaningful realities capable of containing our po tential for imaginative expansion beyond the boundaries of the senses. Without these fictive realities human life becomes a dull animal creature. Without unseen atoms, imaginary chemical formulas, or even such fictive entities as id, ego, and superego, the entire domain of culture becomes a flat, irrelevant world of sensory appearance". (Pargament 2007).

Melihat pentingnya posisi agama sebagaimana diatas maka perlunya manusia untuk kembali kepada aturan agama tidak hanya pada waktu manusia mengalami keterpurukan semata, melainkan agama menjadi word view, dan dasar landasan dalam menjalani proses kehidupan. Seorang individu tidak jarang pula mengalami stres yang ujungnya akan memicu munculnya perilaku-perilaku menyimpang. Agama memiliki peranan penting dalam mengelola stres, melalui peran agama seorang individu akan mendapatkan pengarahan atau bimbingan, dukungan, dan harapan, seperti halnya pada dukungan emosi

Salah satu pedekatan Islami berbasis spiritual dalam agama Islam dikenal dengan ajaran tasawwuf, ajaran ini banyak digunakan sebagai metodologi dalam penyembuhan dan perbaikan psikis seseorang. Menurut Hamdani Adz Dzakiy metode ini adalah peleburan diri dari sifat-sifat, karakter dan perbuatan yang menyimpang dari kehendak dan tuntuna illahi (Bakran Adz-Dzaky 2015).

Pada metode ini proses terapi terbagi menjadi tiga, yakni: Pertama, Takhalli, yaitu pengosongan diri dari bekas-bekas kedurhakaan dan pengingkaran atau dosa melalui Taubatan Nasuha. Pada fase ini seorang klien dibawa pada tahapan penyucian jiwa, mental, akal dan fikiran, qolbu dan moral dengan sifat sifat terpuji. Beberapa teknis penyucian i ni diawali dengan membersihkan diri dari najis melalui istinja' dengan benar, mensucikan kotoran/hadast besar dengan mandi jinabah secara benar, mensucikan yang bersih dengan berwudhu, mensucikan yang suci dengan menjalankan shalat 


\section{Puspo Nugroho}

taubat serta memohon ampun kepada Illahi dan mensucikan yang maha suci dnegan memperbanyak lantunan dzikir dan mentauhidkan Allah dengan lafal "laa ilaha illa Allah".

Kedua, Tahalli yaitu klien dibawa untuk mampu menyelami dan mengisi diri dengan ibadah-ibadah, ketaatan serta aplikasi ketahidan dan akhlak terpuji. Menurut Hamdani bakran adz-Dzaky pada tahap ini terdapat lima langkah; a) seorang klien dibawa pada konsep tauhid "laa ilaha illa Allah" dalam aplikasinya klien diajak untuk merenungi bahwa sejatinya tidak ada yang maha berbuat kecuali Allah, tidak ada yang maha Berencana kecuali Allah, tidak ada yang maha bersifat kecuali Allah, tidak ada yang maha berdzat kecuali Allah, sehingga diharapkan apabila seorang klien telah melalui fase ini ia akan terbebas dari perilaku syirik lahir maupun batin. b) klien diajak untuk memperbaiki pemahaman dan aplikasi syariat, esensinya adalah melaksanakan segala perintah dan menjauhi segala laranganya. c) perbaikan pemahaman dan aplikasi thariqoh, esensinya secara terminologi thoriqoh adalah perjalanan seseorang pencari kebenaran mencari tuhan dengan cara menyucikan diri dan mendekat sedekat mungkin kepada tuhan. Pada tahap ini menyesuaikan dengan tingkatan keilmuan seseorang mulai dari yang sifatnya seorang yang awam, menengah dan atas. d) perbaikan pemahaman dan aplikasi hakikat dan e) perbaikan pemahaman dan aplikasi ma'rifat.

Kesemuanya tersebut harus dilalui secara baik dan benar, sehingga seseorang akan mampu mencapai tahapan yang ke tiga yaitu Tajalli. Tajalli dalam makna bahasa dapat diartikan sesuatu yang tampak, terbuka, menampakkan atau menyatakan diri. Pada tahap inilah Allah ta'ala menampakan dirinya seluas luasnya kepada hambanya yang dikehendakiNya yang pada akhirnya akan memunculkan pribadi dan jiwa jiwa martabat insan khamil.

Spiritualitas merupakan peningkatan hidup beragama yang bersumber pada religiusitas. Dalam penghayatan agama orang yang memiliki spiritual memahami dogma, menjalankan ibadat, melaksanakan moral, dan mendayagunakan lembaga agama secara berbeda dan dalam tingkat yang lebih tinggi dari pada orang yang menjalankan agama (Hardjana 2005). 


\section{Paradigma Pendekatan Spiritual dalam Layanan Bimbingan ...}

Sebagaimana dijelaskan oleh Imaduddin bahwa perkembangan spiritualitas dalam konteks pelaksanaan Bimbingan dan konseling saat ini menunjukkan perkembangan yang sangat pesat (Imaduddin 2017). Hal ini didasari adanya beberapa kajian penelitian yang dipaparkan oleh Gallup, Young, Wiggins-Frame, \& Cashwell, (2007) yang menunjukan bahwa pemanfaatan aspek spiritual memiliki dampak positif dalam penanganan permasalahan fisik dan mental.

Munculnya beberapa lembaga pengobatan jiwa atau pondok pesantren yang menerapkan pendekatan spiritual agama dalam proses layanan bimbingan dan konseling seperti Pondok pesantren Suryalaya di Tasikmalaya dan beberapa lembaga terapi lainya menunjukkan bahwa jiwa manusia memiliki ranah tersendiri yang berbeda dan tidak sekedar hanya pendekatan dan teknik bimbingan dan konseling manual akan tetapi memerlukan pendekatan yang jauh bisa memperbaiki susunan jiwa manusia. Istilah yang sering dipakai adalah psikoterapi religius. Dari beberapa psikoterapi Islam yang pernah dilakukan, sebagai contohnya terapi zikir, terapi ini diyakini sebagai salah satu terapi yang mampu menumbuhkan rasa aman, tentram dan ketenangan yang mendalam sebagai anugerah dari Allah (tumakninah)(Nida 2014: 144).

Berbicara mengenai spiritualitas tentunya tidak bisa dipisahkan dari nilai-nilai agama. Ada keterkaitan antara nilai agama dan nilai moral atau kebaikan yang ada pada setiap agama. Masing masing agama memiliki konsep spiritual dan konsep moral yang antara keduanya saling menyatu. Spiritualitas adalah potensi batin manusia yang perlu dibangun sebagai landasan dalam proses bimbingan dan konseling. Pelibatan aspek spiritualitas dalam proses layanan konseling ketika dimanfaatkan dengan baik bisa menjadi pendekatan yang efektif dalam rangka memfasilitasi perubahan, harapan, dan pencerahan terhadap diri klien (Ingersol, 2004; Bowen-Reid \& Harrell dalam Dailey, 2011)

Terapi spiritual Islami memandang bahwa keimanan dan kedekatan kepada Allah adalah merupakan kekuatan yang sangat berarti bagi upaya perbaikan pemulihan diri dari gangguan depresi ataupun problem-problem kejiwaan lainnya, dan menyempurnakan kualitas hidup manusia (Razak, Kamal Mokhtar, and Wan Sulaiman 
2013:145). Dengan penguatan spiritual pada diri konseli diharapkan mampu membangun konsep diri yang kuat sehingga akan mampu memberikan korelasi terhadap hal-hal positif seorang klien.

\section{Simpulan}

Dari rangkaian diatas penulis berkesimpulan bahwa munculnya penyakit-penyakit ataupun kerusakan kerusakan di dunia ini disebabkan karena jauhnya jiwa manusia dari sang pencipta jiwa itu sendiri. Pada posisi ini tradisi atau ritual praktik keagamaan menjadi sangat penting untuk dilaksanakan sebagai langkah perbaikan terhadap jiwa manusia tersebut. Dengan kembalinya susunan jiwa manusia kepada fase normal diharapkan muncul kebaikan-kebaikan dalam diri manusia yang pada akhirnya akan memberikan efek positif terhadap lingkungan sekitar. 
Paradigma Pendekatan Spiritual dalam Layanan Bimbingan ...

\section{Daftar Pustaka}

A Mukti, Ali. 1991. Metode Memahami Agama Islam. Jakarta: Bulan Bintang.

Adi, I.R. 2008. Intervensi Komunitas Pengembangan Masyarakat Sebagai Upaya Pemberdayaan Masyarakat. Jakarta: Raja Grafindo Persada.

Amti, Prayitno dan Erman. 2008. Dasar-Dasar Bimbingan Dan Konseling. Jakarta: Rineka Cipta.

Bakran Adz-Dzaky, Hamdani. 2015. Konseling \& Psikoterapi Islam. Yogyakarta: Al-Manar.

Cashwell, Craig S., and J. Scott Young, eds. 2011. Integrating Spirituality and Religion into Counseling: A Guide to Competent Practice. 2nd ed. Alexandria, VA: American Counseling Association.

Hardjana, Agus M. 2005. Religiositas,Agama Dan Spiritualitas. Yogyakarta: KANISIUS.

Ibrahim, Farid Wajdi. 2014. ILMU-ILMU USHULUDIN MENJAWAB PROBLEMATIKA UMAT ISLAM DEWASA INI. Ar-Raniry: International Journal of Islamic Studies 1(1): 41-58.

Imaduddin, Aam. 2017. Spiritualitas Dalam Konteks Konseling. Journal of Innovative Counseling: Theory, Practice \& Research 1: 1-8.

Iqbal, Muhammad. 1940. The Reconstruction of Religious Thought in Islam. Cambridge: Cambridge University Press.

Jalaludin. 2010. Psikologi Agama. Jakarta: Rajawali Press.

Kadir, Muslim A. 2003. Ilmu Islam Terapan: Menggagas Paradigma Amalai Dalam Agama Islam. Yogyakarta: Kerjasama STAIN Kudus dengan Pustaka Pelajar.

Kilmer, Colleen. 2012. INTEGRATING SPIRITUALITY AND RELIGION INTO COUNSELING. Winona State University: 34.

Mahmud. 2011. Metode Penelitian Pendidikan. Bandung: Pustaka Setia.

Muhtar. 2014.SPIRITUAL APPROACH TO SOCIAL REHABILITATION OF DRUG ABUSE VICTIMS IN BOARDING INABAH SURABAYA. Jurnal INFORMASI Vol. 19, No. 3, September-Desember(3): 250-259. 
Nida, Fatma Laili Khoirun. 2014. Zikir Sebagai PsikoteraPi Dalam Gangguan Kecemasan Bagi Lansia. Konseling Religi 5(1).

Nugroho, Puspo. 2017. INTERNALISASI NILAI-NILAI KARAKTER DAN KEPRIBADIAN MAHASISWA PENDIDIKAN AGAMA ISLAM MELALUI PENDEKATAN HUMANIS-RELIGIUS. Edukasia: Jurnal Penelitian Pendidikan Islam 12(2): 355-382.

Pargament, Kenneth I. 2007. Spiritually Integrated Psychotherapy: Understanding and Addressing the Sacred. New York: Guilford Press.

Rahman, Fazlur. 1964. Islam Dan Modernity; Transformation of an Intellectual Tradition. Chicago: The University of Chicago Press.

Razak, Ahmad, Mustafa Kamal Mokhtar, and Wan Sharazad Wan Sulaiman. 2013. TERAPI SPIRITUAL ISLAMI SUATU MODEL PENANGGULANGAN GANGGUAN DEPRESI. Jurnal Dakwah Tabligh 14(1): 141-151.

Syafri, Fatrida Anugrah, and Muhamad Rifa'i Subhi Rifa. 2017. PEMANTAPAN PSYCHOLOGICAL SELF CONCEPT PESERTA DAN AGAMA. Journal of Innovative Counseling: Theory, Practice \& Research 1: 24-30.

Syukur, M. Amin. 2003. Teologi Islam Terapan: Upaya Antisipatif Terhadap Hedonisme Kehidupan Modern. Solo: Tiga Serangkai.

Syahdan Alamsyah, di https://news.detik.com/berita-jawa-barat/d3995324/begini-langkah-polisi-ungkap-pesta-spiritus-maut-disukabumi? _ga $=2.72774803 .1232520902 .1532738121$ 1212079979. 1532738121

Reinhard Soplantila, di https://news.detik.com/berita/d3919271/pelajar-sma-di-makassar-sembunyikan-24-paketsabu-di-cd?_ga=2.72774803. 1232520902. 15327381211212079979.1532738121

Andri Saubani, 2018. KPAI: 16 Anak Meninggal Akibat Kekerasan pada 2018 Diakses dari https://www.republika.co.id/berita/nasional/hukum/ 18/03/26/ p66zma 409- kpai-16-anak-meninggal-akibatkekerasan-pada-2018 